\title{
Increasing the Creative Economy through Utilization of Fruit Wrapping Waste and Food Bags as Decorative Flowers Crafts in Langon, Ambulu District of Jember Regency
}

\author{
Author \\ Reni Umilasari (Orcid ID: 0000-0001-5491-7373) \\ Ilanka Cahya Dewi (Orcid ID: 0000-0002-6027-9889) \\ Correspondence \\ Program Studi Teknik Informatik, Universitas Muhammadiyah Jember \\ Program Studi Teknik Sipil, Universitas Muhammadiyah Jember \\ reni.umilasari@unmuhjember.ac.id, ilankadewi@unmuhjember.ac.id
}

\begin{abstract}
The Covid-19 pandemic caused the number of unemployed to increase in 2020. The National Development Planning Agency (Bappenas) stated that the unemployment rate is expected to increase by 4 million to 5.5 million in 2020 and around 7.7 per cent to 9.1 per cent in 2021. This, of course, has an impact on the economic condition and welfare of the community. One of the efforts that can be made to prevent and reduce the unemployment rate is by creating new jobs so that efforts to increase the creative economy must always be carried out to support the formation of new jobs.

Increasing the quality of human resources, efforts to increase the creative economy can be made. In this Stimulus Community Partnership Program (PKMSS) activity, a concrete manifestation of increasing skills and knowledge can be done by providing decorative flowers made from fruit wrapping/sarong waste and food bags to PKK RT 003 RW 030 women in Langon Hamlet, Ambulu Village District Ambulu. In addition, marketing activities through social media or marketplaces will also be given special training. The objectives of this PKMSS activity include: (1) Increasing the knowledge and skills of the community in waste management that are commonly encountered daily; (2) reducing the amount of waste for fruit wrappers and food bags; (3) Creating new business opportunities, especially for PKK RT 003 RW 030 women in Langon Hamlet, Ambulu District. Quoting data from CupoNation Indonesia, domestic ecommerce platforms still control the number of website visitors throughout 2019 even though several international online shopping sites are also included in the ranks of the e-commerce market in Indonesia. Therefore, digital-based marketing training through social media or e-commerce needs to be given to expanding product marketing.
\end{abstract}

Keywords: creative economy, waste, decorative flowers, crafts, fruit wrappers.

Received: 01 April 2021. Accepted: 22 June 2021

\section{Introduction}

More than $50 \%$ said to be not indigenous; that is, they are categorized as migrants. This area is classified as an area that has experienced very rapid development, especially in the trade sector, thus providing opportunities for newcomers to compete to make a living in this area. Most of the population is in the young age group. So that this demographic condition shows that the human resource potential of the Jember Regency is quite adequate as a potential provider and bidder for labour in the labour market. However, since the beginning of 2020, as we all know, the Covid-19 pandemic has resulted in the number or number of unemployed increased in 2020. The National Development Planning Agency (Bappenas) reported by the Minister of National Development Planning (PPN) that the open unemployment rate was projected to increase by 4 million to 5.5 million in 2020 and around 7.7 per cent to 9.1 per cent in 2021. If this continues, it is feared that until 2021 unemployment will reach 10.7 million 
to 12.7 million. This, of course, has an impact on economic conditions and the welfare of society.

One of the efforts that can be made to prevent and reduce the unemployment rate is by creating new jobs so that efforts to increase the creative economy must always be carried out to support the formation of new jobs. For example, by opening a business on a home industry scale, its implementation must pay attention to strategies in developing the business. Creating new jobs to support the increase in the creative economy must be accompanied by different ideas and innovations. It can also affect market progress and increase revenue.

It is improving the quality of human resources to improve the creative economy that can be done. The more qualified the existing human resources, the wider the contribution in developing the business is specific. Because starting from adequate human resources, ideas and creative ideas emerge to improve product quality, service quality to increase sales. Have skills and knowledge following the times and technology so that it will be easier to expand the business.

The concrete manifestation of increasing skills and knowledge that can be done is activities proclaimed in the Community Partnership Program Program, which is planned to provide training in making decorative flowers made from fruit wrapping waste and food bags for PKK RT 003 RW 030 women in Langon Hamlet, AmbuluDistrict. In addition, marketing activities through social media or marketplaces will also be given special training. The expectations of this PKMS activity include:

1. Increase the knowledge and skills of the community in the utilization of waste which is commonly found daily.

2. We are reducing the amount of waste for fruit wrappers and food bags.

3. We are creating new business opportunities, especially for PKK RT 003 RW 030 women in Langon Hamlet, Ambulu District.

4. Social media is a medium of buying and selling because there are more and more social media users in today's era, especially during a pandemic.
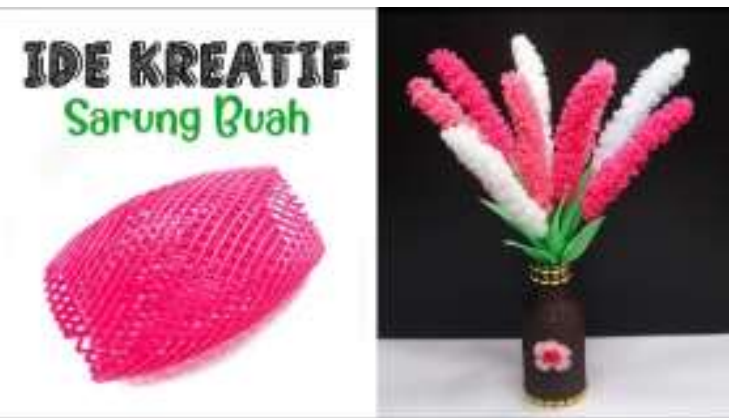

Figure 1. Decorative flower made from fruit wrapping waste.

\section{Methods}

The approach used in this PKMS is direct training and creativity development by preparing all the necessary materials in advance. For this activity to run sustainably, it is essential to assist PKK RW 030 Hamlet Langon, Ambulu Village, both from product production activities, namely ornamental flowers and marketing activities planned to be carried out online through social media. The output of this activity is expected that the community will have skills that encourage an increase in the creative economy in terms of forming a business unit in the form of decorative flower crafts.

Stages of activities to obtain solutions in the field of decorative flower production training activities to form a new business unit that can reduce the amount of fruit sarong and food bag waste so that it has a selling value to increase the creative economy In detail, the 
solutions, outputs and stages in the entire series of PKMS activities can be seen below.

\section{a. Tutorial of Making Decorative} Flower Output: The establishment of a PKK women's group business unit with products in the form of decorative flowers.

Stage:

1. Discuss the bio of the person in charge.

2. Discuss tools and materials.

3. Prepare tools and materials

4. Conducting decorative flower doing training.

5. Discuss strategies for developing into a household business form.

\section{b. Training on How to Make Decorative Flowers From Apple Wrapping Output: Instagram,} Facebook and Marketplace accounts

1. Create an account according to the product name filled in from iOS / Android.

2. Complete bio with contacts to contact.

3. Posting a website link on the profile.

4. Discuss hashtags that will often be added in the caption.

5. Install the "Follower Chief" application and discuss its uses.

6. Discuss tips for optimal use of Instagram, such as quality of content, posting time, and the average number of posts in a day.

7. We are registering an account on the Marketplace, such as shopee, tokopedia, Bukalapak, etc.

8. Create a summary or product details.

9. Uploading product images on social media and marketplaces.

\section{Result and Discussion}

Economic development continues to undergo a transformation process in line with changes in resource availability and community needs. The limited availability of natural resources encourages the emergence of a new paradigm in economic development. Economic growth no longer depends on the availability of natural resources but rather on the elements of creativity and innovation that human resources can carry out. The financial sector that moves with this impetus is then known as the industry or creative economy.

Jember Regency is an area that is still lagging in the field of education, which requires creative and innovative residents to develop their business. To encourage the realization of a productive society in the era of the Covid-19 pandemic, a group of lecturers and students at the University of Muhammadiyah Jember conducted Community Service Activities (PKM) entitled "Increasing Creative Economy through Utilizing Fruit Wrapping Waste and Food Bags as Decorative Flower Crafts in Langon Hamlet. Ambulu District ". Community Service Activities (PKM) are carried out online using a zoom application which consists of two sessions. On January 22, 2021, the first session focused on making decorative flowers using used fruit sarongs and used cloth bags to wrap food. Meanwhile, the second session was training on marketing techniques using social media. The teams that carry out training activities are as follows:

1. Reni Umilasari, S.Pd., M.Si (Chief Executive)

2. IlankaCahyaDewi, M.T (Member 1)

3. SukmaNurulAini (Member 2)

This activity was initiated with the general objective of developing the skills of PKK RT 003 RW 030 women through the production of decorative flowers made from waste fruit sarongs and used food wrapping bags. In addition, training activities are also focused on introducing online markets among PKK mothers so that they hope to increase the marketing of ornamental flower products that will be produced by PKK RT 003 RW 030 DusunLangon, Ambulu Village. One of them is introducing how to use social media and the Marketplace for buying and selling activities.

The following is a series of PKMS activities at RT 003 RW 030 Langon Hamlet, Ambulu Village.

1. Preparation of tools and materials needed some apple wrappers

- Several plastic bags and cloth used for food wrapping

- Several wooden sticks of various sizes to make vases

- Foam

- Vase

- Clear tape / UHU glue 
- Scissors

- Wire to produce flower stalks

- used food wrapping bags to make leaves

2. Tutorial of Making Decorative Flower Various types of flowers can be produced using used fruit sarongs and plastic bags or cloth bags used for food wrapping, one of which is as shown in Figure 1. The steps are as follows:

1. Cut the plastic into small pieces.

2. Arrange the plastic in a stack, tie the centre, and then trim it to form a circle resembling a flower crown.

3. Cut the wire according to the size of the flower stalk to be made.

4. Cover the wire with a cloth bag used for food bags.

5. Make a leaf pattern on a cloth bag used for food bags, then cut out the leaves.

6. Tie the flowers at the ends of the wire.

7. Arrange the leaves neatly at the bottom of the flower.

8. Put into a vase that has been prepared. Flower vases can also be made using ice cream sticks attached to the foam to resemble a tube so that the flower stalks that have been made can be filled.
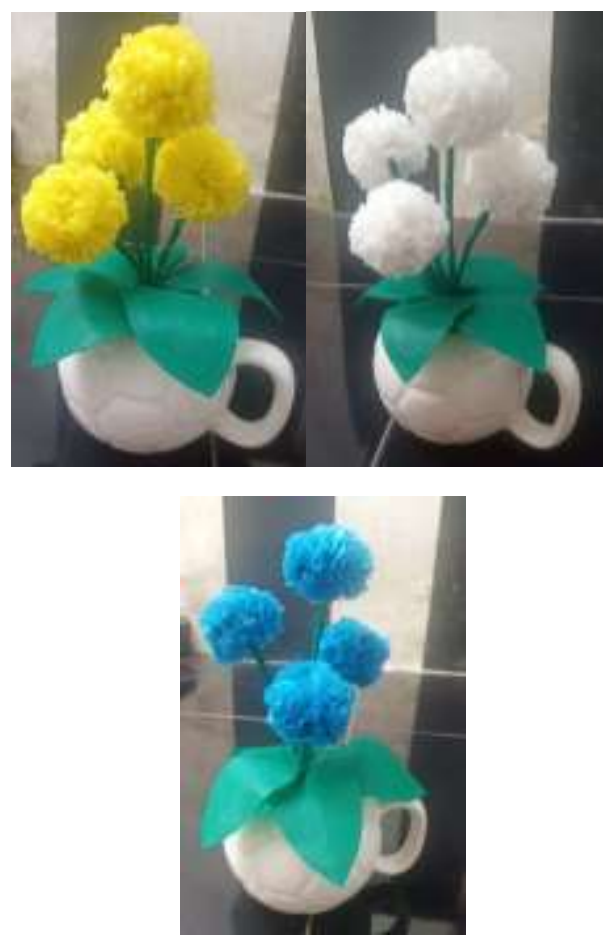

Figure 1. Examples of Decorative Flowers Made from Food Bags

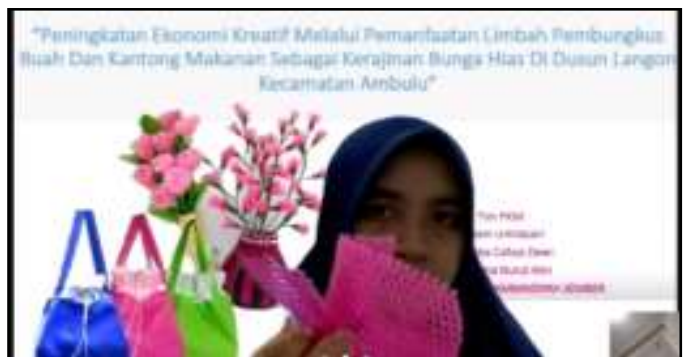

Figure 2. Training on How to Make Decorative Flowers From Apple Wrapping

An example of a decorative flower made from an apple scabbard with a flower vase made from ice cream sticks can be made in the following steps:

1. Put the foam into the vase.

2. Insert the wooden stick into the foam, then attach the leaves to the pot with masking tape or UHU glue.

3. After drying, wash the used apple wrappers; the shape resembles a flower (as imitated or other forms). Then stick it to the end of the wooden stick.

4. Flower decoration from apple wrap is ready to beautify the room.

3. Marketing Training Using Social Media and Marketplace

Online buying and selling activities are nowadays, but not all people understand how to buy goods online or even sell goods online on social media and the Marketplace. For example, the PKK RT 03 RW 30 group in Langon Hamlet, Ambulu District, incidentally consists of homemakers. In this PKMS activity, the Lecturer and Student team from the University of MuhammadiyahJember introduced what a marketplace is and how to register as a seller in the Marketplace, as shown in Figure 3. Some tips so that the products we sell can sell well were also conveyed by resource persons of the PKMS Team, including:

1. complete the shop profile;

2. there is a description and photo of the product;

3. provide a choice of a variety of shipping services;

4. Affordable prices;

5. provide promos regularly; 

6. promote your stall and products;

7. take advantage of marketplace features; and

8. Serve customers well.

In general, PKMS activities attended by PKK RT 03 RW 30 women in Langon Hamlet, Ambulu District, went well. The mothers had great enthusiasm and were able to understand the material presented well. Following a series of PKMS activities, it is hoped that PKK RT 003 RW 030 women will develop skills through the production of decorative flowers made from waste and master the use of social media and market places as new means of buying and selling process.

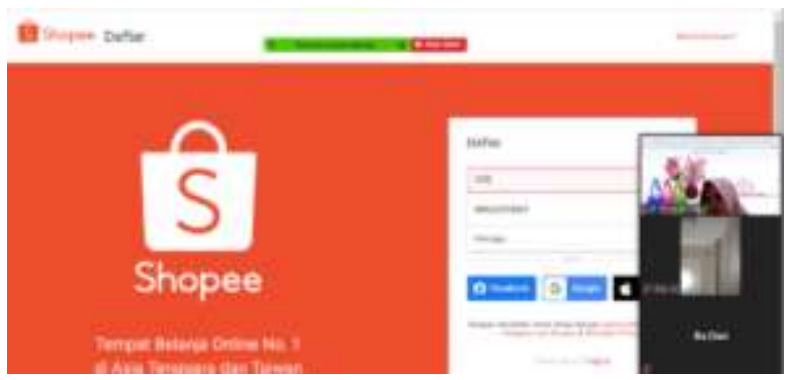

Figure 3. Training on How to Make an Online Store in the Marketplace

\section{Conclusion}

The 2021 Stimulus Community Partnership Program (PKM) entitled "Increasing Creative Economy through Utilizing Fruit Wrapping Waste and Food Bags as Decorative Flower Crafts in Langon Hamlet, Ambulu District" has been implemented well. The organizer has conducted online training using the zoom meeting application, which consists of two sessions: training on making decorative flowers and training on product marketing using social media and the Marketplace. From this PKMS activity, it is hoped that PKK RT 003 RW 030 women will develop skills by producing ornamental flowers made from waste and master the use of social media and marketplaces as new means of the buying and selling process.

\section{References}

Andityadan Tito FrankyNasution. 2010. Trik Sukses Menjadi Pengusaha Properti. Yogyakarta: CV. Andi Offset.

C Audrey. 2013. Panduan Membuat dan Menghias Antaran Mahadan Souvenir Pernikahan. Yogyakarta: Kawan Pustaka.

Dewanti, Retno. 2008. Kewirausahaan. Mitra Wacana Media, Jakarta.

LPPM UM Jember. 2020. Panduan Pengabdian Internal Edisi III. Jember: LPPM UM Jember.

LPPM UM Jember. 2020. RencanaStrategis Program kemitraanmasyarakat stimulus 2020-2024. Jember: LPPM UM Jember.

LPPM UM Jember. 2020. Rencana Induk Penelitian 2020-2024. Jember: LPPM UM Jember.

Lupiyoadi, Rambat, 2007. Entrepreneurship from Mindset To Strategy, Cetakan Ketiga, Lembaga Penerbit Fakultas Ekonomi Universitas Indonesia, Jakarta. 